Magdalena Wieczorkowska

Medical University of Lodz

Faculty of Health Sciences

Chair of Humanities, Department of Sociology

e-mail: magdalena.wieczorkowska@umed.lodz.pl

\title{
Ethical dilemmas of aesthetic medicine: Between restorative medicine and the commercialisation of the body"
}

\begin{abstract}
Technological advances in medicine have given the sick and the disabled a chance of making a full recovery. However, contemporary trends show that medicine goes far beyond its restorative functions. The increasing popularity of plastic surgery raises many questions. Is medicine beginning a new era of its development as a response to the commercialisation of the human body? Does not correcting nature lead to people's segregation into the better and the worse ones?

The development of medical technologies has accelerated the commercialisation of the body by treating it as a package that one can "redecorate" to be more attractive in the market of social relations. Plastic surgery is trying to solve the identity crisis and psychological problems of people. New forms of medicalisation are emerging. A lack of success is seen as a symptom of a disease that can be cured with a scalpel.

Plastic surgery can be a tool of reconstruction of one's identity but only under strict circumstances (genetic defects, bodily injuries). By posturing as a solution to people's psychological and sociological problems, medicine must reckon with a moral/ethical critique.
\end{abstract}

Keywords: plastic surgery, commercialisation of the body, medicalisation

JEL Classification: I11, I12

\footnotetext{
* The article is an updated version of the paper published in Polish in the Annales. Ethics in Economic Life, 10(2), 95-102.
} 


\section{Introduction}

The fact that humans have bodies is undeniable. However, the answer to the question of where the boundary between the physical and social body lies is not so obvious. If it is possible to function with artificial organs, support life with an apparatus or change the appearance through surgery, where does the "pure" or "natural" man end?

The world is becoming increasingly uncertain; during the last two decades expressions such as the culture of fear (Furedi, 2007) or the risk society (Beck, 2012) have emerged. Uncertainty concerns not only the condition of the natural environment or the state of world security but also what the human body is. Being a subject of medical interest for many centuries, it has become one of the most medicalised elements of the contemporary world. Technological advances in medicine have created enormous possibilities, giving hope for fitness and recovery to the sick, handicapped and injured in accidents, allowing for early diagnosis that saves lives of millions of people in the world, and enabling us to look inside the human body and remove defects that formerly excluded man from functioning in society.

However, currently observed trends indicate that medicine has gone beyond curative and restorative functions understood as providing help to those in need. Today, medical activities often concern "repairing normality". The growing popularity of plastic surgery, compounded by the media, makes us ask whether medicine is entering a new phase associated with the technological progress as a response to the commercialisation of the body. Does not correcting nature lead to segregation of people into the better ones (i.e. surgically corrected) and the worse ones (characterised by a lower market value)? And consequently, does aesthetic medicine, whose aim is to eliminate uncertainty about one's body, not give birth to this uncertainty anew?

In the author's opinion, technological advances in medicine have accelerated the commercialisation of the human body, making it into a package that can be modernised and improved, thus increasing an individual's attractiveness in the labour market. The body becomes a product, an investment that determines the position of a human being in the arena of interpersonal relations. Aesthetic medicine (or plastic surgery, dental surgery, ophthalmology, sports medicine, etc.) seeks to solve the identity crisis and psychological problems of contemporary people. Further manifestations of medicalisation are emerging. A healthy person is a person improved by surgical procedures that change not only his or her appearance but also personality. A lack of success and self-confidence or an unsuccessful marital life are symptoms of a disease that can be cured with a scalpel. 


\section{The sociology of the body and the sociology of health, disease and medicine}

The presented considerations draw theoretical inspirations from the sociology of the body and the sociology of health, disease and medicine. Within the first of the mentioned sub-disciplines of sociology, three main approaches can be distinguished: issues related to the social regulation of the body, the ontology of the body and the experiencing of the body (Nettleton, 2005).

The social regulation of the body. This perspective focuses on the influence of social institutions on the regulation, control, monitoring and use of the human body. Our bodies are subjected to careful "treatment" from the moment of birth the aim of which is to suppress and channel natural instincts to build the so-called social body. The constant conflict between nature and culture, between reason and emotions, resurfaces here. Many authors are interested in the way institutions of religion, law or medicine regulate the human body. The most evident influence of these three institutions can be seen at the birth and death of the human body, but there is also debate over topics such as abortion, euthanasia or organ transplants. It is worth noting here that in this perspective feminist movements, which have made the issue of the regulation of the female body by all kinds of institutions one of their central issues, have found their place. The control of the human body, manifested in a variety of forms, is to serve primarily to maintain social order. The theorists of this trend indicate that throughout the whole life of man the human body is subject to two types of regulations: the first one consists in "training" the human body to specific behaviours, and the main mechanism in this respect is socialisation whose task is to encourage people to hide their natural instincts and behaviours under the mask of socialised conduct. We learn to wear a special type of clothing, how to behave in specific situations, and what should not be done or must not be done. The other type of regulations is based on continuous control of the effects obtained in the first stage. Institutions established for this purpose have a set of penalties and rewards by means of which they effectively enforce the required behaviour. Individuals whose bodies do not follow such regulations are isolated and go to hospitals or prisons.

The lived body. According to this trend, the human body determines the way in which one explores and responds to the world. The perception and experiencing of the world are rooted in the senses of sight, touch, smell, hearing and taste, i.e. the elements that undoubtedly belong to human corporeality. Through this corporeality, the outer world appears to us and our reactions to it are born. Usually, we are unaware of this fact, because we are also ignorant of the existence of our own body. ${ }^{1}$ We feel it only when its dysfunction appears - a cold, fracture, contusion, or haemorrhage. A disease often forces us to rebuild our consciousness and how we perceive our body. A great deal of considerations is also devoted to new tasks and possibilities that stand before the body and the embodied self of a sick person. This perspective has appeared as a response to the dualism of the soul and body, nature and

\footnotetext{
${ }^{1}$ In relation to this condition, the term health in a vacuum, proposed by the French researcher C. Herzlich, is used (cf. Puchalski, 1990, pp. 321-331).
} 
culture, reason and emotions popularised in the literature. Proponents of this approach argue that it is impossible to separate these two entities from each other, as there is constant interaction between them. The body and the soul are a unity that manifests itself most fully in a situation of illness, suffering and pain. Somatic complaints are accompanied by specific emotions - anger, sadness, or a sense of powerlessness.

The ontology of the body (body projects). This last perspective is the most important here, as it focuses on the dilemmas of aesthetic medicine. The growing uncertainty of the surrounding world means that the human body has begun to be perceived as fragile, delicate, unreliable, and therefore requiring constant improvements and enhancements. At the same time, people have begun to see that the human body is the seat of the self, the place where the human soul is hidden. This has additionally intensified the willingness to care for the packaging of such noble content. The human body has started to be perceived as a process, it has become a "project" that is developed and carried out throughout an individual's life. Body projects, as this phenomenon is defined in the discussed perspective, have become the basis for an individual's self-identification. Genetic engineering, a healthy diet, physical activity, cosmetic procedures and plastic surgery are just some examples of such "projects". It turns out, however, that what was to contribute to the rebuilding of self-confidence creates an even greater sense of uncertainty. The boundary between the body and its image is becoming blurred. Increasingly, the reflection, the image of the body itself - the ECG, X-ray or computed tomography-becomes more reliable than the actual person. The image of the body becomes the basis for its transformation. Nowadays, aesthetic medicine more often creates the image of a human being than simply eliminates existing defects. In many television stations, one can watch programmes in which people, mainly women, undergo painful and risky surgical procedures in the name of beauty, self-confidence and success. It would not be possible if it were not for medical technological advances that can form human bodies like the sculptor's hands create a statue. However, this is associated with several threats that will be discussed further on.

The other sub-discipline - the sociology of health, disease and medicinefocuses on the social construction of health and disease concepts, a reflection on medicine itself, its organisation and medical professions as well as the relationship between medical science and social sciences. In its context, one can speak about the social consequences of changes in medicine. Medical advances and health education have changed the structure of diseases from acute to chronic, have caused the emergence of a holistic model of health and disease as a response to the biomedical model, and have increased health awareness of modern societies as well as the importance of the concept of health and disease as social constructs, not only objective products of evidence-based medicine (Ostrowska, 2010; Skrzypek, 2013; Sokołowska, 1986; Straus, 1957). Especially since health has become a commercialised, commoditised category, it deserves consideration. There has been a transition from "being healthy" to "having health", making it a commodity, changing the definition of the disease, and thus blurring the already fluid boundary between the common understanding of health and disease. 


\section{The body and its image}

Corporeality is associated mainly with the physical dimension, is proof of our existence, and the permanent absence of the body indicates the end of our biological life. Ever since ancient times, however, the human body has also had other dimensions - the psychological one, associated with experiencing one's organism and its perception by an individual, as well as the social one, whose essence is related to other people and how they perceive the body of an individual. Therefore, since the beginning of time, the body has been subjected to rituals, customs and treatments aimed at embellishing, modifying, displaying, decorating or covering its certain parts. The most common procedure is to hide the body under layers of clothing. Nudity, in the Bible, is associated with the feeling of shame and is inseparable from the original sin. Having committed the sin, the first people "realised that they were naked". Nowadays deprived of clothes, we feel naked, exposed, but not only in the physical dimension but above all in the spiritual dimension. Clothing conceals the imperfections of our beauty, but also of our conscience. In addition, without clothing, we become extremely like each other, ordinary, average. Clothes are something that sets us apart in a way, makes us richer or poorer, having better or worse taste, while in the face of nakedness we only differ in terms of sex.

Nowadays, the external appearance has become the most important trademark of a person which determines his or her economic, professional, family and social position. The ways of dressing, doing one's hair and makeup, the complexion, the body shape and body structure promoted in the media show at the same time the ideals of a woman and a man that are desirable and appropriate. The external appearance determines inclusion or exclusion from a given social group. Newspapers, magazines, television, cinema, and the music industry define patterns of appearance that are fashionable. The way these patterns are presented means that they also become desirable. As in the past, the advertisement showed that a person could become someone better, more valuable, less frustrated, happier or more attractive thanks to the acquisition of a specific product, today television shows that to achieve it one only needs to undergo plastic surgery.

The human body has ceased to be treated as permanent and immutable. This change in perception has an ontological meaning, as it forces us to revisit the answer to the question of what the human body is. For centuries, it was treated as permanent, immutable and, among others, because of that fact, it was not an object of interest in social sciences. In sociology, it appeared incidentally as the basis for social activities, but not as an object of a separate scientific reflection. Anthropology was the first to make the body the centre of study, showing its diversity, dissimilarity of treatment and use. ${ }^{2}$ In sociology, the body appeared through the sociology of sport, followed by the sociology of the body and medicine. ${ }^{3}$ The body has ceased to be something that "is", nowadays one "has", "possessed", "modifies",

\footnotetext{
${ }^{2}$ It is worth referring to works of Marcel Mauss or Bronisław Malinowski.

${ }^{3}$ Currently, this sub-discipline is called the sociology of health, disease and medicine.
} 
and "creates" the body (Bauman, 2006; Buczkowski, 2005; Featherstone, 2008, pp. 109-117; Shilling, 2010; Turner, 2008). The body is treated as a process and as a "project". It has become a long-term investment that is supposed to provide benefits, prestige, and respect. Thus, the flexible body is subjected to many modifications throughout the entire human life, depending on the needs or desires of a given individual. At the same time, it is perceived as the most important element of human personality. Jan Szczepański's classic concept distinguishes biogenic elements (of which the body is part) as well as psychogenic and sociogenic personalities (Szczepański, 1972). The body is also an important element of Ralph Turner's self-image and self-conception (Turner, 2006, pp. 272-284). The selfimage is a "photograph" of our "self" which we see at a specific moment and which changes from moment to moment (Turner, 2006). The self-conception is a permanent "picture" of our "self", the concept of who we really are. If the body of an individual ceases to be permanent and becomes "fluid", it also has consequences for such lasting constructs as the self-conception. Interest in body makeover programmes, ${ }^{4}$ in which ordinary people decide to "remodel" their bodies, shows not only the economic dimensions of the play between demand and supply of commercial medical services but also the social transformation of orientation towards hedonistic and consumerist values. According to Wolfgang Welsch, referred to by Agnieszka Maj (2013, p. 85), today's man is homo aestheticus, i.e., an "educated hedonist"- a sensitive, conscious person with a sublime taste, ready to shape and stylise his or her soul and body.

As the programmes show, many people deciding to undergo plastic surgery believe that with their new noses or breasts their well-being will improve, their self-confidence will increase and, therefore, the quality of their lives will be enhanced. The first programmes on this subject did not take into consideration possible side effects, which might suggest that the procedures were a safe technique for improving one's appearance. Currently, information on side effects appears in the programmes, the convalescence process is also shown, which somewhat balances the optimistic and pleasant image of plastic surgery. Moreover, there are also programmes showing the side effects of plastic surgery. ${ }^{5}$ Many formats also show people for whom aesthetic medicine is the last chance for a normal life and full social activity (victims of accidents, diseases, people with congenital malformations and deformities). In this way, two separate types of medicine are presented-restorative medicine and medicine that fulfils desires. The former gives a chance for a normal life, restoring a healthy look and self-confidence, counteracting social exclusion and stigmatisation. The latter makes life better, easier, more beautiful; pleasant medicine that makes an individual's life better and an individual him or herself healthier. This division is equally unfavourable for patients as well as medicine itself. On the one hand, it somewhat alleviates the

\footnotetext{
${ }^{4}$ Examples of such programmes on Polish television are, among others: "Secrets of Plastic Surgery", "Life Without Shame", "I Want a Famous Face", "The Swan", "Make Me Beautiful".

5 Examples of such TV programmes available in Poland include "Cosmetic Surgery from Hell," "Botched".
} 
hedonistic orientation of aesthetic medicine itself, but on the other hand, the confrontation of the healthy and the sick that avail of its offer falls to the disadvantage of the former, accused of vanity.

The contemporary image of the body contradicts somewhat demographic trends. On the one hand, we are dealing with the so-called greying population, which is a result of the decline in the number of births and the extension of the length of human life. On the other hand, there is no place for old age in modern societies. It is associated with illness, suffering, powerlessness and social uselessness, and above all with a deformed body, which becomes unattractive, unsightly, wrinkled, and distorted. Technological advances have contributed to a significant extension of human existence, and now attempts are being made to mask this achievement with the help of plastic surgery. Medicine has become a cure and a weapon at the same time. Old age has been medicalised and is treated like a disease. Death begins to be perceived as an "accident at work" made by a doctor which soon can be prevented. And elderly people as a social category are marginalised, sidelined, even though in many countries they constitute a huge percentage of the population. Old age is unfashionable and unwanted, and modern generations are no different from the main character in The Picture of Dorian Gray who wanted to preserve his youth at all costs. According to surveys conducted by the Centre for Public Opinion Research (CBOS) from 2017, as much as $87 \%$ of Poles attach great importance to their own appearance (Cybulska, 2017). According to the same report, the look is of great importance both in personal life and professional career. As far as the personal sphere is concerned, as much as $38 \%$ of the respondents believe that the appearance has a large impact on the success of a person in life, while for $32 \%$ the appearance determines the success of a person in life. In the professional sphere, the responses were $37 \%$ and $33 \%$, respectively (Cybulska, 2017). According to the GfK Beauty report from 2016, the external appearance reflects well-being for $35 \%$ of the respondents.

The determinants of beauty in women are now symmetry and proportionality of the figure and face, well-groomed appearance, smooth and radiant skin without discoloration, wrinkles and pimples, unnecessary hair, and the body structurefrom a slim figure to anorexic thinness. The determinants of male beauty are also proportionality and symmetry, as well as a muscular body structure, clean skin and neat nails, and increasingly often a lack of characteristic male hair. Added to this is a radiant smile with white teeth and elegant fashionable attire for both sexes. Old age has no place in this scenario; if someone wants to age with dignity, they must cover up the signs of entering the golden years. Only in this way will they not be excluded from society, the labour market, and the social relations market. 


\section{Aesthetic medicine-service to people or commercial activity?}

Aesthetic medicine is a branch of medical aesthetics understood as a subdiscipline of medicine dealing with the prevention of skin aging and improving the physical attractiveness of the patient (by restoring or improving the natural appearance) (Śpiewak, 2012, pp. 70-71).

Treatments aimed at modifying the human body have been known for millennia (Koziński \& Zaczyński, 2006). In the $6^{\text {th }}$ century BC in India, reconstructions of the nose, ears and mouth were carried out, while in China since the 10th century AD women's feet were bound because the ideal was a woman with small feet. In the Turkish literature of the 11 th century, descriptions of operations of drooping eyelids and gynecomastia procedures appeared. Pioneering facelifts, often ending in patients' death due to the materials used-a solution of arsenic and lead-were carried out in the 19th century in Great Britain. In the $20^{\text {th }}$ century, surgical procedures became even more popular, and at the same time more invasive. In the 1920s, women had their ribs removed to give them the slim wasp waist. Such a procedure was allegedly performed on Pola Negri. Marilyn Monroe also owed her face and image to plastic surgery-to make her face shapelier, a sponge implant was sewn into her chin. It was reportedly replaced every five years. The first plastic surgery clinic was opened in the United States in 1921 and was founded by a Polish surgeon, Jacek Maliniak.

The 1960s were a period of popularisation of silicone breast implants. In 2000, Botox was invented, which became a commonly used means for smoothing wrinkles, and in 2004, operations rejuvenating voice were initiated. Michael Jackson and Cher, who since 1988 have underwent numerous plastic surgeries and became the icons of plastic surgery. In 2004, 12 million plastic surgeries were performed in the United States (Koziński \& Zaczyński, 2006, p. 55).

Currently, plastic surgeries are a fashionable Holy Communion gift in Brazil and are very popular among the Chinese families with adolescent daughters. In the 2003 CBOS study (Biały, 2003), only 1\% of the respondents admitted to having undergone a beautifying treatment, in 2009 it was 2\% (Pankowski, 2009). How many people really want to do this is evidenced by the number of applications for the Polish edition of the "Make Me Beautiful" programme. As many as 100,000 Polish women are ready to change their body to find a better job, a partner, to repair marital relations, or to get rid of complexes. Breast enlargement or liposuction become a remedy for many problems of a psychological or social naturethese treatments are aimed at solving financial problems (finding a job) or even supplementing intellectual deficiencies (a more beautiful and well-groomed person is also a wiser, better-educated person). Individuals are becoming increasingly insecure about themselves and their abilities. To increase chances in the labour market or social relations, a person undergoes treatments believing that they will contribute to this goal. Medicine today meets social expectations. Thanks to technological advances, medicine can save lives even in the most hopeless situations. However, it is becoming a threat to many spheres of human functioning by medi- 
calising them. Work, professional success, social life, sexual life or earnings cease to be dependent on personality traits, intellect, education, and become dependent on the offer of aesthetic medicine.

Progress in medicine has two faces. On the one hand, achievements in this field have given hope for health and life to many millions of sick, handicapped and disabled people. Organ transplants or artificial organs prolong the lives of many people with dysfunction of specific parts of the body, and restore mobility to handicapped people, artificial insemination gives hope to many married couples who have difficulty with having children, specialist equipment sustains vital functions, monitors body parameters and is used for complicated procedures, while plastic surgery enables the removal of congenital defects and injuries or damage resulting from accidents. On the other hand, medicine has contributed to the acceleration of the commercialisation of the body. It has become a commodity with a clearly defined price and market value, depending on the investments made. This second face of medicine becomes morally ambiguous, for example, because it contributes to the segregation of people into the better and worse ones, more and less valuable. Economic disparities are becoming more pronounced as not everyone can afford these aesthetic medical services. The cost of liposuction is approx. PLN 3,900, abdominoplasty-PLN 4,900, breast enlargement-PLN 3,500, breast reduction-PLN 4,900, cheek lifting-PLN 3,900, and eyelid surgery-PLN 2,900 (Sarnowicz, 2006). Added to this are dental procedures (one implant costs approx. PLN 8,000), dermatological treatments (Botox-PLN 1,000), beautician's and hairdresser's services as well as designers' consultations usually combined with the change of wardrobe. The prices vary significantly and depend on the prestige of the clinic, as well as the medical procedure used (equipment, the form of treatment, materials, etc.). Nevertheless, these are not cheap procedures. Therefore, those who can afford the costs are made more beautiful, becoming even more attractive, desirable or rich. Most people are only left frustrated, and this frustration is the cumulative effect of dissatisfaction with one's own body and economic constraints preventing its change. Such people are left only with the possibility of participating in television programmes in which they make an exhibitionist act of having their bodies publicly improved.

Medicine, manipulating the human body, also manipulates the mind and personality of man. Plastic surgery carries a huge risk of psychological problems for both patients and their immediate environment. For many people, it seems that after the surgery not only their appearance will change, but also their character, personality, and financial, marital as well as social problems will disappear. Reality after the surgery verifies this illusion quite quickly, leaving scars on the body and soul. Very often, plastic surgery is a threat to the youngest members of the patient's family, as children do not recognise a new face of their parent or relative after surgery. This can have very serious negative consequences in the relationship between the person who has undergone the procedure and the child.

What is the purpose of contemporary aesthetic medicine-repairing what has been damaged, or creating something new, better, based on what was old and good? In other words, does the doctor have the right to model the patient's body 
according to the preferences of the latter, despite a lack of health reasons, or should medicine help only when the patient's life and health are in danger? This question does not concern only plastic surgery, but also genetic engineering that enables manipulation of the human genome or prosthetics, i.e. implantation of artificial organs. The answer should consider the medical, psychological, social and economic aspects, as it is impossible to talk about these issues and not to mention their commercial dimension. This question about the purpose of aesthetic medicine can be extended to medicine in general. Not only has the body becomes a commodity, health in general has become commoditised, and the state of one's depends not on the biological conditions but on one's financial resources.

Aesthetic medicine is commercial medicine, market-oriented, which has little to do with social service or conscience. Each doctor has the right to refuse to perform a medical procedure citing the clause of conscience. Nobody has heard of such a behaviour among plastic surgeons or dentists, but it is quite common, for example, among gynaecologists. Of significance is probably the fact that aesthetic medicine is basically a completely private activity, while gynaecological services are performed both privately and state-run institutions. ${ }^{6}$ A private practice often has completely different rules and a system of values. As it is a commercial activity, it is subject to market regulations, not moral regulations. Improvement and beautification become more important than medical treatment.

A serious consequence of medicalisation of old age and popularisation of plastic surgery is the commercialisation, and thus the commoditisation, of the human body. Medical specialisations have already introduced a significant fragmentation of man into individual organs, treated by many doctors narrowly specialised in the pathology of a specific organ. The patient is dehumanised and ceases to be an actor or a partner and is perceived as a sick pancreas or a badly prognostic cancer. Aesthetic medicine further deepens this depersonalisation, assigning a material value to the human body, just as the price of a car and its individual parts are established. A facelift begins to resemble the straightening of a car's body after an accident. Advice by stylists and make-up artists is comparable to needing a new paint job, and dental implants - a set of new tires. This "repaired" man "leaves" the beauty salon and enters the world where the cult of youth and success dictates the rules.

\section{Conclusions}

General medicine is currently generating many discussions about its achievements, discoveries and activities, as well as the effects of these activities. The definition of health comprises an overall well-being including physical, mental

\footnotetext{
${ }^{6}$ It is a completely different matter to hide behind the clause of conscience in a state-run facility, while at the same time unscrupulously performing abortions or prescribing contraceptives in private practice. These phenomena, however, though pathological, have slightly different origins and merit a separate study.
} 
and social dimensions instead of using the absence of illness or disability as the criteria. However, ways to achieve this well-being are changing, and technological advances are being widely used. On the one hand, medicine is focused on saving human life. Its basic principle is "do no harm". It should be emphasised, however, that this does not refer only to a purely medical dimension, in the form of iatrogenic errors, but also to mental and social harm that is far more serious in its consequences. On the other hand, medicine is increasingly commercialised, becoming one of many service-provided companies. Its goal ceases to be the change from the "bad" state to the "good" state, but increasingly often the goal is the change from the "good" to the "better" state. This is particularly visible in the field of aesthetic medicine, which is extremely commercialised nowadays. This fact has several negative consequences, such as:

(1) psychological effects of cosmetic procedures and plastic surgery, not always in line with patients' expectations;

(2) an increase in social inequalities and progressive polarisation between the very rich and very poor, the beautiful and ugly, the improved and damaged;

(3) financial consequences associated with the need to repeat some treatments;

(4) social consequences related to new fashions and new ideals of beauty and success redefine interpersonal relationships that were once based on knowledge, experience, opinions or interests, and are replaced by the external appearance;

(5) making the external appearance a value in the labour market equal to knowledge and skills;

(6) the fluidity of "self", instability of the self-conception, and consequent mental imbalance leading to emotional and personality disorders;

(7) moral consequences related to blurring the boundary between what is real and natural, and what is artificial and created.

Aesthetic medicine can be a tool for rebuilding one's identity, but only in justified cases (genetic defects or personal injuries due to accidents). However, by offering its services as a key to solving personal and professional problems, medicine can lead to disturbances in the sphere of self-image and self-conception, and therefore, must reckon with moral objections.

\section{References}

Bauman, Z. (2006). Płynna nowoczesność (T. Kunz, Trans.). Kraków: Wydawnictwo Literackie.

Beck, U. (2012). Społeczeństwo światowego ryzyka (B. Baran, Trans.). Warszawa: Wydawnictwo Naukowe Scholar. 
Biały, K. (2003). Dbałość o wlasna sylwetkę [research report No. BS/154/2003]. Warszawa: CBOS.

Buczkowski, A. (2005). Społeczne tworzenie ciała. Płeć kulturowa i płeć biologiczna. Kraków: Universitas.

Cybulska, A. (2017). Czy jesteśmy zadowoleni ze swojego wyglądu? [research report No.104/2017]. Warszawa: CBOS.

Featherstone, M. (2008). Ciało w kulturze konsumpcyjnej. In M. Szpakowska (Ed.), Antropologia ciata. Zagadnienia i wybór tekstów (pp. 109-117). Warszawa: Wydawnictwo Uniwersytetu Warszawskiego.

Furedi, F. (2007). Culture of fear revisited. London-New York: Continuum.

GfK. (2016). Dbanie o urodę jest dla Polaków bardzo ważne. GfK Beauty 2016 report results. https://www.gfk.com/pl/aktualnosci/press-release/dbanie-o-uro de-jest-dla-polakow-bardzo-wazne/

Koziński, A., \& Zaczyński, M. (2006, February 5). Lepsze ciało = lepsze życie. Wprost, 5, 50-57.

Maj, A. (2013). Ciało jako ponowoczesny "projekt estetyczny”. Estetyka i Krytyka 28(1), 83-92.

Nettleton, S. (2005). The sociology of the body. In W. C. Cockerham (Ed.), The Blackwell Companion to Medical Sociology (pp. 42-63). Oxford: Blackwell Publishers Ltd.

Ostrowska, A. (Ed.). (2010). Socjologia medycyny. Podejmowane problemy, kategorie, analizy. Warszawa: Polska Akademia Nauk.

Pankowski, K. (2009). Polak zadbany - troska o sylwetke $i$ wtasne ciato [research report No. BS/130/2009]. Warszawa: CBOS.

Puchalski, K. (1990). Kryteria zdrowia i choroby. In A. Gniazdowski (Ed.), Zachowania zdrowotne (pp. 321-331). Łódź: Instytut Matki Polki.

Sarnowicz, E. (2006). Doktor kontra doktor. An interview with Maria Noszczyk, MD and Bartłomiej Noszczyk, MD PhD. Twój Styl, March.

Shilling, Ch. (2010). Socjologia ciała. Warszawa: Wydawnictwo Naukowe PWN.

Skrzypek, M. (2013). Socjologia medycyny w multidyscyplinarnych badaniach humanizujacych biomedycynę. Lublin: Wydawnictwo Katolickiego Uniwersytetu Lubelskiego.

Sokołowska, M. (1986). Socjologia medycyny. Warszawa: Państwowy Zakład Wydawnictw Lekarskich.

Straus, R. (1957). The nature and status of medical sociology. American Sociological Review, 22(2), 200-204.

Szczepański, J. (1972). Elementarne pojęcia socjologii. Warszawa: Państwowe Wydawnictwo Naukowe.

Śpiewak, R. (2012). Estetologia medyczna, medycyna estetyczna, dermatologia estetyczna, chirurgia estetyczna, ginekologia estetyczna, stomatologia 
estetyczna - definicje i wzajemne relacje poszczególnych dziedzin. Estetologia Medyczna i Kosmetologia, 2(3), 70-71.

Turner, B. S. (2008). The body and society. Explorations in social theory. New York: Sage Publications.

Turner, R. H. (2006). Koncepcja siebie w interakcji społecznej. In A. JasińskaKania, L. M. Nijakowski, J. Szacki, \& M. Ziółkowski (Eds.), Współczesne teorie socjologiczne, (vol. I, pp. 272-284). Warszawa: Wydawnictwo Naukowe Scholar.

Wieczorkowska, M. (2007). Dylematy etyczne medycyny estetycznej - medycyna naprawcza, czy urynkowienie ciała? Annales. Ethics in Economic Life, 10(2), 95-102. 